\title{
НАЛОГОВО-БЮДЖЕТНАЯ БЕЗОПАСНОСТЬ МУНИЦИПАЛЬНЫХ ОБРАЗОВАНИЙ В АСПЕКТЕ РЕГИОНАЛЬНОЙ ЭКОНОМИКИ
}

\author{
(c) 2020 Котов Роман Михайлович \\ кандидат экономических наук, доцент кафедры бухгалтерского учета, \\ анализа, аудита и налогообложения \\ Кемеровский государственный университет, Россия, Кемерово \\ (c) 2020 Инденко Оксана Николаевна \\ кандидат технических наук, доцент кафедры прикладной математики \\ Кемеровский государственный университет, Россия, Кемерово \\ E-mail:yana_for_27@mail.ru
}

В результате проводимых в Российской Федерации реформ особую значимость приобретает вопрос устойчивости и безопасности финансов муниципальных образований. Муниципальные образования любого региона играют важную роль в развитии территорий, повышении их экономического потенциала, развитии социально-экономического развития, в повышении уровня качества производства, повышении уровня и качества жизни населения.

Целью статьи является исследовать роль и место налогово-бюджетной безопасности муниципальных образований в региональной экономике. Задачи исследования: 1. Изучить подходы к определению термина «налогово-бюджетная безопасность; 2. Рассмотреть исторические этапы становления налогово-бюджетной безопасности в России; 3. Дать характеристику налогово-бюджетной безопасности муниципальных образований.

Ключевые слова: муниципальные образования, налоговая безопасность, бюджетная безопасность, расход бюджета муниципальных образований, методы исследования.

Актуальность исследования обусловлена тем, что закрепленные законодательно за местными органами власти полномочия существенно расширили функции муниципальных образований в сфере обеспечения жизнедеятельности населения, что потребовало дополнительных налогово-бюджетных ресурсов. Однако предлагаемый в рамках реформы финансовый механизм не может обеспечить достаточный уровень налогово-бюджетных доходов муниципальным образованиям. Подавляющее большинство местных бюджетов по-прежнему находится в неудовлетворительном положении, что не гарантирует выполнение органами местного самоуправления социально-экономических функций.

В условиях реформирования бюджетной сферы и налоговой системы Российской Федерации налогово-бюджетная безопасность муниципальных образований приобретает значительную роль. На современном этапе на фоне глобализации и экономической нестабильности уровень налогово-бюджетного развития муниципалитета имеет тенденцию к дифференци- ации. С позиции субъекта Российской Федерации такая ситуация объясняется наличием не стабильной динамики развития проблемных муниципалитетов и увеличением уровня федеральных дотаций в них. Такая диспропорция в развитии муниципалитетов нуждается в исследовании с позиции налогово-бюджетной безопасности и моделей его регулирования. Однако в научной литературе недостаточно исследованы современные особенности обеспечения налогово-бюджетной безопасности муниципальных образований. В настоящее время нет единого подхода к определению и обеспечению налогово-бюджетной безопасности. Данный факт создает предпосылки для совершенствования подходов к комплексной оценке налоговобюджетной безопасности муниципальных образований, которая должна отражать влияние факторов и процессов, происходящих в региональных территориях, и будет оказывать влияние на стратегические решения региональных властей в отношении муниципалитетов. Исследование налогово-бюджетной безопасности муниципальных образований обусловлено их низ- 
кой резистентностью к внутренним и внешним угрозам. В свою очередь данный факт объясняется отсутствием финансовой самостоятельности и самодостаточности муниципалитета.

В этой связи целесообразно дать определение налогово-бюджетной безопасности. Будем рассматривать данный термин в аспекте экономической безопасности. Понятие «безопасность» трактуется как «защищенность жизненно важных интересов от внешних и внутренних негативных воздействий, при которой создаются нормальные условия функционирования и возможность стабильного развития» [4].

«Экономическая безопасность - это область научного знания, в рамках которой изучают состояние экономики, при котором обеспечивается достаточно высокий и устойчивый рост экономических показателей; эффективное удовлетворение экономических потребностей; контроль государства за движением и использованием национальных ресурсов; защита экономических интересов страны на национальном и международном уровнях» [4]. Одним из элементов экономической безопасности является финансовая безопасность. Финансовая безопасность должна отвечать таким критериям оценки, которые характеризуют уровень развития финансовой системы, экономических процессов в государстве, которые создают условия для социально-экономического развития государства, для поддержания целостности и единства финансовой системы России. Данное обстоятельство формирует понятие финансовой безопасности как элемента для успешного преодоления внешних и внутренних угроз в сфере финансов и экономики как в масштабе страны, так и в масштабе регионов и их муниципальных образований.

Налогово-бюджетная сфера является основным элементом финансовой безопасности. От налогово-бюджетной безопасности зависит уровень обороноспособности страны, уровень социальной защиты населения, уровень развития здравоохранения и образования, так как эти направления являются главными в стратегии развития государства. На сколько будет продумана налогово-бюджетная система государства, на столько будут слажено работать все звенья экономики, удовлетворяться потребности государства и населения.

Объектом налогово-бюджетных отношений муниципальных образований является процесс реализации доходных и расходных полномочий публично-правовых образований, установленных в законодательном порядке, необходимых для исполнения ими своих функций и удовлетворения общественных потребностей. Субъектами налогово-бюджетных отношений муниципальных образований выступают местные органы законодательной власти и управления, а также экономические субъекты.

Налогово-бюджетная безопасность муниципальных образований должна обеспечивать социально-экономическую защиту общества. Социальные проблемы имеют место быть на всех уровнях экономической системы государства. На уровне муниципалитетов решаются самые первостепенные задачи социальной защиты населения, связанные с его жизнеобеспечением. Эффективность социально-экономическое развития общества зависит от обеспечения финансовыми ресурсами и модели управления муниципалитетом. Муниципальный бюджет выполняет две важные функции:

1. Источник расходных полномочий;

2. Влияние местных органов власти на масштабы производственной деятельности с помощью налоговых платежей, уровень которых устанавливается в рамках их полномочий.

Данные функции оказывают влияние на сбалансированность бюджета муниципальных образований, что в свою очередь оказывает влияние на социально-экономическое развитие региона в целом.

В последние годы налогово-бюджетная безопасность муниципальных образований приобретает особую актуальность. Причинами тому являются многочисленные налоговые нарушения, задолженности по налоговым платежам муниципальных образований перед государственным бюджетом. Существенное влияние на налогово-бюджетную безопасность муниципальных образований оказывает функционирование налогового администрирования. Именно от нее зависит безопасность государственных финансов, следовательно, и способность государства реализовывать основополагающие функции по обороноспособности страны, социальной защите населения, а также здравоохранения и образования. От продуманности и адекватности налогово-бюджетной системы зависит развитие региональной экономики в целом. Субъектами налогово-бюджетных отношений муниципальных образований выступают мест- 
ные органы законодательной власти и управления, а также экономические субъекты.

В результате проводимых в Российской Федерации реформ особую значимость приобретает вопрос устойчивости и безопасности финансов муниципальных образований. Функционирование муниципальных образований, направлено на решение задач местного развития. От продуманности и адекватности налогово-бюджетной системы зависят субъекты налогово-бюджетных отношений муниципальных образований, которыми выступают местные органы законодательной власти и управления, а также экономические субъекты. На современном этапе налогово-бюджетная безопасность реализуется по двум направлениям: безопасность бюджетной и налоговой системы муниципальных образований. Для того чтобы понять, что такое «налогово-бюджетная безопасность муниципальных образований», рассмотрим декомпозицию данного понятия [9].

Налогово-бюджетная безопасность муниципальных образований характеризуется:

1) балансом бюджетной системы муниципальных образований, который предполагает отношения элементов бюджетной системы, при котором обеспечивается ее целостность;

2) наличием бюджетных резервов, под которыми понимается заранее обособляемая часть бюджетных средств, предназначенная на финансирование непредвиденных расходов государства.

Базисным элементом финансовой системы региона является налогово-бюджетная сфера. Основным нормативно-правовым актом Российской Федерации, регламентирующим деятельность муниципальных образований, является Федеральный Закон «Об общих принципах организации местного самоуправления в Российской Федерации» N 131-Ф3, который устанавливает общие правовые, территориальные, организационные и экономические принципы организации местного самоуправления в Российской Федерации.

Путь становления налогово-бюджетного сферы в Российской Федерации сложен и многообразен. В процессе формирования российской модели бюджетного федерализма механизмы выравнивания бюджетной обеспеченности неоднократно менялись. Выделяют следующие этапы становления налогово-бюджетных отношений [9].
I этап (1991-1993 гг.) - стадия «стихийной децентрализации» налогово- бюджетных отношений. Данный период времени характеризуется формированием новой бюджетной системы Российской Федерации, целью которой было построение основ межбюджетных отношений. II этап (1993-1998 гг.) - характеризовался углублением кризиса налогово-бюджетных отношений. III этап (1999-2000 гг.) - реформа становления налогово-бюджетных отношений. IV этап (20012005 гг.) - развитие налогово-бюджетного федерализма. В обозначенный период времени завершилось формирование Фонда финансовой поддержки регионов, которые законодательно были закреплены на федеральном уровне. $\mathrm{V}$ этап (2006 г.- настоящее время) - повышение эффективности налогово-бюджетных отношений и качества управления финансами. В данный период времени возникло противоречие, которое выражается в том, что были сформированы местные бюджеты, но при этом одновременно возникла напряженная ситуация при взаимодействии разных уровней власти. Бюджетная система должны быть обеспечена таким уровнем безопасности, который позволил бы муниципалитету быть платежеспособным в отношении реализации социальной политики, сохранять баланс доходов и расходов, контролировать целевое использование бюджетных средств.

Налогово-бюджетную безопасность муниципальных образований определяют по характеристикам, представленным на рисунке 1.

Из рисунка 1 видно, что существует 5 характеристик налогово-бюджетной безопасности муниципальных образований [7]:

1. термин «сбалансированность бюджета» отражен в виде принципа бюджетной системы и означает соотношение расходов и поступлений в бюджет муниципальных образований, их пропорциональное изменение в условиях экономической неопределенности;

2. целостность бюджетной системы муниципальных образований предполагает такое взаимодействие элементов бюджетной системы, при котором обеспечивается ее целостность и единство;

3. бюджетное финансирование является одной из форм покрытия расходов и осуществляется на основе принципов безвозвратности и целенаправленности;

4. под бюджетными резервами понимается заранее обособляемая часть бюджетных 


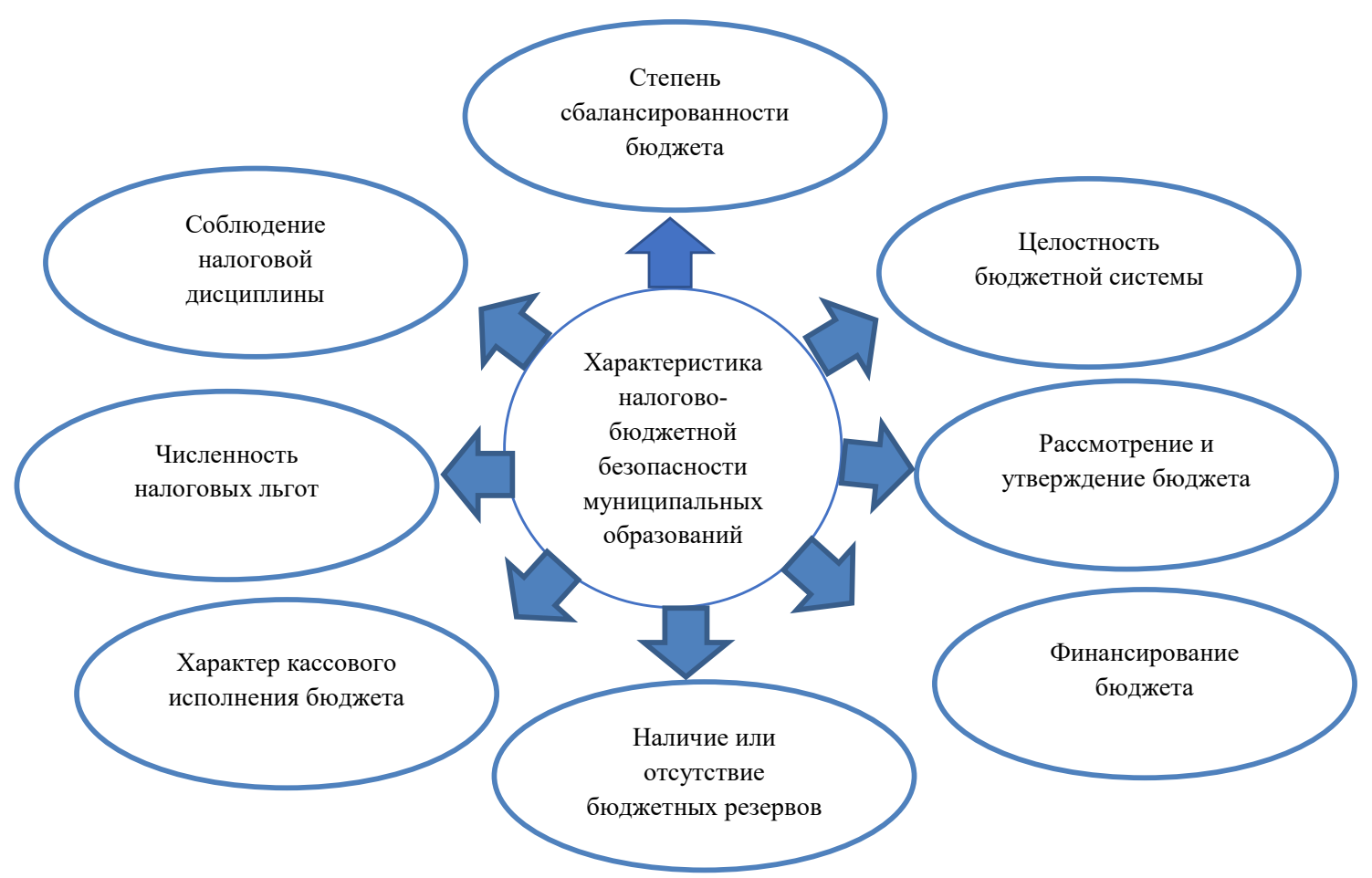

Рисунок 1. Характеристика налогово-бюджетной безопасности муниципальных образований

средств, предназначенная на финансирование непредвиденных расходов государства;

5. налоговые льготы подразумевают предоставление налоговым законодательством полное или частичное освобождение от уплаты налога;

В этом случае целесообразно заключить, что настоящая налоговая система оказывает прямое влияние на налогово-бюджетную безопасность муниципальных образований. Это объясняется основной функцией налоговой системы - обеспечение муниципального бюджета за счет налоговых платежей. Данное условие выполнимо только при оптимальном сочетании качества управления и развития социальной и производственной сферы.

Таким образом, обеспечение экономической безопасности в налогово-бюджетной сфере яв- ляется важным звеном в развитии, стабильном и эффективном функционировании региональной экономики. Однако на налогово-бюджетную сферу влияют угрозы, как из внешних, так и из внутренних источников, что негативно влияет на экономику региона и государства в целом. Для того чтобы функционирование налоговобюджетной сферы способствовало развитию и стабилизации экономики необходимо разрабатывать пути ее повышения. Размер бюджета в целом определяет уровень налогово-бюджетной безопасности муниципальных образований. Основные критерии оценки при этом следующие: объем перераспределения валового регионального продукта через бюджет, причины, размер и уровень дефицита бюджета, формы финансирования и его масштабы, уровень бюджетной дисциплины и целевое его использование.

\section{Библиографический список}

1. Громова А.С.Бюджетно-финансовая безопасность и экономический рост как критерии проведения экономической политики государства / А. С. Громова // Известия Томского политехнического университета.2017.- № 6.- C. $42-45$.

2. Жидкова, Е.А. Основные предпосылки экономической и финансовой устойчивости развития экономики региона / Е.А. Жидкова, В.П.Зотов: монография: Кемерово: Полиграф, 2013.-156 с.- Текст: непосредственный. Авторский вклад 4,87 п.л. 
3. Изотова Г.С. Методы обеспечения безопасности бюджетной системы региона / Г.С.Изотова.- М.: Инфра-М, РИОР, 2015.- 296 с.

4. Никулина Е.В. Моделирование и прогнозирование налогово-бюджетной безопасности регионов России: монография / Е. В.Никулина, И. В. Чистникова, А. В. Орлова.- Белгород: ООО «Эпицентр», 2015.-100-110 с.

5. Райзберг Б. А. Государственное управление экономическими и социальными процессами / Б. А. Райзберг М.: НИЦ Инфра-М, 2014.- 384 с.

6. Смоланова О.В.Индикативный анализ налогово-бюджетной безопасности муниципальных образований региона / О.В. Смоланова // Регионология. - 2016. - № 3.- С. 1-5

7. Ткачева T.Ю. Современные тенденции формирования налогово-бюджетной безопасности региона / Т. Ю. Ткачева // Известия Юго-Западного государственного университета. - 2017. - № 2 (47). - С. 55-61.

8. Ускова Т.В. Бюджетная безопасность региона в контексте устойчивого развития / Т. В. Ускова // Проблемы развития территории.-2014.- № 4.- С. 24-33.

9. Черкасова Ю.И. Бюджетно-налоговый потенциал в финансовом регулировании региона: монография / Ю. И. Черкасова. - 2016. - № 17-180 с. 